\title{
Mobilitas Penduduk, Kemiskinan, dan Ketahanan Pangan di Daerah Bencana: Kasus Desa Timbulsloko, Kecamatan Sayung, Kabupaten Demak, Provinsi Jawa Tengah
}

\author{
Sukamdi \\ Fakultas Geografi, Universitas Gadjah Mada, Yogyakarta dan Pusat Studi Kependudukan dan \\ Kebijakan, Universitas Gajah Mada, Yogyakarta \\ Korespondensi: Sukamdi (e-mail: sukamdi@ugm.ac.id)
}

\begin{abstract}
Abstrak
Tujuan dari penelitian ini adalah untuk menjelaskan hubungan antara migrasi, kemiskinan, dan pemenuhan permintaan makanan. Desain penelitian adalah metode campuran, menggabungkan metode survei dan kualitatif. Survei dilakukan dengan melibatkan 100 sampel rumah tangga yang dipilih secara acak. Sementara itu, metode kualitatif dilakukan dengan wawancara mendalam kepada rumah tangga terpilih dan informan kunci. Hasil penelitian ini menunjukkan bahwa dampak banjir rob terhadap ekonomi masyarakat sangat signifikan. Sebagai contoh, lebih dari seperlima rumah tangga termasuk ke dalam kategori miskin (pengeluaran per kapita di bawah garis kemiskinan). Salah satu penyebabnya adalah banjir rob telah mengakibatkan hilangnya sebagian besar mata pencaharian masyarakat dari pertanian. Selain itu, hilangnya lahan pertanian juga telah mengakibatkan hilangnya sumber daya pangan. Pada akhirnya, hal tersebut menyebabkan sebagian besar rumah tangga bergantung pada pekerjaan nonpertanian, yaitu sebagai buruh di luar desa. Sebagai konsekuensinya, mereka harus melakukan mobilitas nonpermanen sebagai cara untuk mengatasi masalah ekonomi yang mereka hadapi. Hal yang menarik adalah mereka tidak ingin bermigrasi ke tempat lain. Salah satu alasan mereka tidak bermigrasi adalah ketidakmampuan mereka mengatasi hambatan antara ekonomi dalam bentuk biaya untuk bermigrasi.
\end{abstract}

Kata kunci: mobilitas penduduk; kemiskinan; ketahanan pangan 


\title{
Population Mobility, Poverty, and Food Security in Disaster Areas: Case of Timbulsloko Village, Sub District of Sayung, District of Demak, Central Java Province
}

\begin{abstract}
The purpose of this study is to explain the relationship between migration, poverty, and fulfillment of food demand. Research design is a mixed method, combining survey and qualitative methods. The survey was conducted involving 100 samples of randomly selected households. While the qualitative method is carried out by in-depth interviews with selected households and key informants. The results of this study indicate that the impact of tidal flooding on the community economy is very significant. For example, more than one fifth of households fall into the poor category (per capita expenditure below the poverty line). One of the reasons is that tidal flooding has resulted in the loss of most people's livelihoods from agriculture. In addition, the loss of agricultural land has also resulted in the loss of food resources. In the end, this caused most households to rely on non-agricultural work, namely as laborers, outside the village. As a consequence they have to carry out non-permanent mobility as a way to overcome the economic problems they face. The interesting thing is they don't want to migrate to other places. One reason why they do not migrate is their inability to overcome economic barriers in the form of costs to migrate.
\end{abstract}

Keywords: population mobility; poverty; food security

\section{Pendahuluan}

Penelitian tentang mobilitas penduduk, termasuk migrasi, yang telah banyak dilakukan sebagian besar adalah penelitian yang menjelaskan tentang penyebab, proses, dan dampak dari migrasi, baik internal maupun internasional. Kajian migrasi juga dikaitkan dengan kemiskinan, bahkan migrasi dapat dipandang sebagai jalan keluar dari kemiskinan (lihat Yen, et.al., 2014).

Sementara itu, ada aspek penting yang dalam beberapa hal tersingkirkan (neglected), yaitu ketahanan pangan. Menggabungkan isu ketahanan pangan dengan migrasi dan kemiskinan merupakan hal penting yang masih jarang dibahas.

Dalam konteks penelitian ini, isu tentang migrasi, kemiskinan, dan ketahanan pangan menjadi lebih menarik karena hal tersebut dikaitkan dengan kondisi daerah penelitian, yaitu daerah yang terkena banjir rob setiap tahun sebagai akibat dari perubahan iklim. Dengan demikian, terdapat satu aspek lain yang menjadikan penelitian ini menarik, yaitu adanya perubahan iklim. Sebagaimana disebutkan oleh Choirul Amin, Sukamdi, dan Rijanta (2018), penelitian yang mengaitkan migrasi dengan perubahan iklim di Indonesia masih relatif jarang dilakukan.

Perubahan iklim pada dasarnya merupakan dampak dari pemanasan global (global warming), yaitu fenomena peningkatan temperatur global dari tahun ke tahun karena terjadinya efek rumah kaca (greenhouse effect) yang disebabkan oleh meningkatnya emisi gas rumah kaca (GRK) dari aktivitas atau kegiatan manusia di seluruh dunia. Banjir rob merupakan salah satu fenomena, efek dari terjadinya pemanasan 
Mobilitas Penduduk, Kemiskinan, dan Ketahanan Pangan di Daerah Bencana:

Kasus Desa Timbulsloko, Kecamatan Sayung, Kabupaten Demak, Provinsi Jawa Tengah

global (global warming). Di masa mendatang, intensitas kejadian fenomena banjir rob dapat diprediksikan semakin tinggi. Terjadinya banjir rob atau banjir pasang air laut dapat menimbulkan pengaruh yang besar bagi masyarakat, terutama yang bertempat tinggal di kawasan pesisir. Salah satu dampak dari fenomena banjir rob di kawasan pesisir dapat terlihat dari perubahan penggunaan lahan yang ada. Perubahan penggunaan lahan akibat banjir rob menjadikan luasan lahanlahan produktif di kawasan pesisir semakin menyempit atau bahkan menghilang. Berkurangnya lahan-lahan produktif yang digunakan sebagai sumber penghidupan akan menimbulkan kerugian yang besar bagi kehidupan masyarakat.

Kabupaten Demak merupakan salah satu daerah yang sering terkena banjir pasang air laut atau banjir rob sejak tahun 1980an. Banjir rob memiliki intensitas kejadian dan tingkat keparahan yang semakin tinggi dengan lama genangan 6-8 jam setiap harinya. Banjir rob yang terjadi secara langsung mengakibatkan adanya perubahan penggunaan lahan di beberapa kecamatan yang terkena. Banjir rob yang terjadi menenggelamkan desa-desa yang ada serta mengakibatkan banyak lahan tambak yang hilang dan bangunan rusak. Kecamatan Sayung, Karang Tengah, Wedung, dan Bonang merupakan empat kecamatan yang sering kali digenangi oleh banjir rob. Kecamatan Sayung merupakan daerah yang terkena dampak paling parah dari banjir rob yang terjadi secara rutin di Kabupaten Demak. Adapun klasifikasi dampak banjir rob di Kecamatan Sayung terbagi menjadi lima kategori, yaitu kerusakan bangunan tempat tinggal, peningkatan salinitas air tanah dan permukaan, kehilangan lahan, kerusakan lahan tambak, serta kerusakan kendaraan/ peralatan kerja (Desmawan, 2012).
Berkurangnya luasan lahan pertanian produktif di Kecamatan Sayung dapat membawa dampak terhadap kehidupan sehari-hari masyarakat. Masyarakat yang bekerja umumnya di bidang pertanian dan perdagangan sangat bergantung kepada ketersediaan lahan-lahan produktif yang ada. Selain itu, keberadaan lahan pertanian produktif juga merupakan hal penting yang perlu diperhatikan terkait dengan ketahanan pangan daerah tersebut beberapa tahun yang akan datang. Berkurangnya lahan-lahan produktif juga dapat berpengaruh terhadap ketahanan masyarakat mengatasi tekanan yang ditimbulkan oleh lingkungan sekitar tempat tinggalnya. Kondisi lingkungan yang kurang menguntungkan, dalam hal ini daerah bencana banjir rob, mampu memengaruhi keputusan menetap atau tidaknya masyarakat sekitar di daerah tersebut.

Tujuan umum penelitian ini adalah menjelaskan hubungan antara mobilitas penduduk, kemiskinan, dan ketahanan pangan.

\section{Metode Penelitian}

Penelitian ini dilakukan di DesaTimbulsloko, Kecamatan Sayung, Kabupaten Demak. Pemilihan lokasi penelitian dilakukan secara purposif. Lokasi penelitian dipilih karena daerah tersebut terkena banjir rob paling parah. Di Kecamatan Demak, Kecamatan Sayung adalah kecamatan yang paling parah terkena rob, sedangkan Desa Timbulsloko adalah desa yang paling parah terkena rob di antara desa-desa lain di Kecamatan Sayung.

Desain penelitian menggunakan mix method, yaitu kombinasi metode kuantitatif (survei) dan kualitatif (field research), melalui concurrent design, yaitu kedua metode dilakukan pada waktu yang (relatif) bersamaan dan keduanya berfungsi sebagai cara untuk melakukan analisis triangulasi. 


\section{Sukamdi}

Populasi dalam survei adalah seluruh rumah tangga di desa lokasi penelitian saat penelitian. Sampel penelitian ini adalah rumah tangga yang dipilih secara acak sederhana. Adapun jumlah sampel adalah 100 rumah tangga yang mewakili total 1.122 rumah tangga yang terdapat di Desa Timbulsloko. Penentuan jumlah sampel dilakukan menggunakan Rumus Slovin dengan tingkat eror sebesar 10 persen. Pengumpulan data dilakukan dengan wawancara terstruktur menggunakan kuesioner yang disusun berdasarkan observasi yang dilakukan sebelum penelitian dilakukan.

Terdapat beberapa variabel yang digunakan untuk menjelaskan setiap tema migrasi, kemiskinan, dan ketahanan pangan. Variabel migrasi meliputi mobilitas penduduk, kejadian banjir rob, dan bantuan dari pemerintah. Kemudian variabel kemiskinan meliputi pekerjaan, penghasilan, pengeluaran, pengeluaran rumah tangga, serta kepemilikan aset.

Sementara itu, dalam metode kualitatif, pengumpulan informasi dilakukan dengan wawancara mendalam terhadap informan terpilih. Ada dua jenis informan dalam penelitian ini, yaitu rumah tangga yang diambil dari sampel survei dan tokoh masyarakat, formal maupun informal. Beberapa aspek yang menjadi fokus dalam wawancara mendalam adalah cara mencukupi kebutuhan pangan, pola mobilitas penduduk, dan strategi bertahan hidup. Analisis data dilakukan melalui tiga tahap. Tahap pertama adalah analisis hasil survei secara deskriptif. Tahap kedua adalah analisis terhadap hasil wawancara mendalam. Selanjutnya tahap ketiga adalah melakukan sintesis antara hasil survei dan wawancara mendalam.

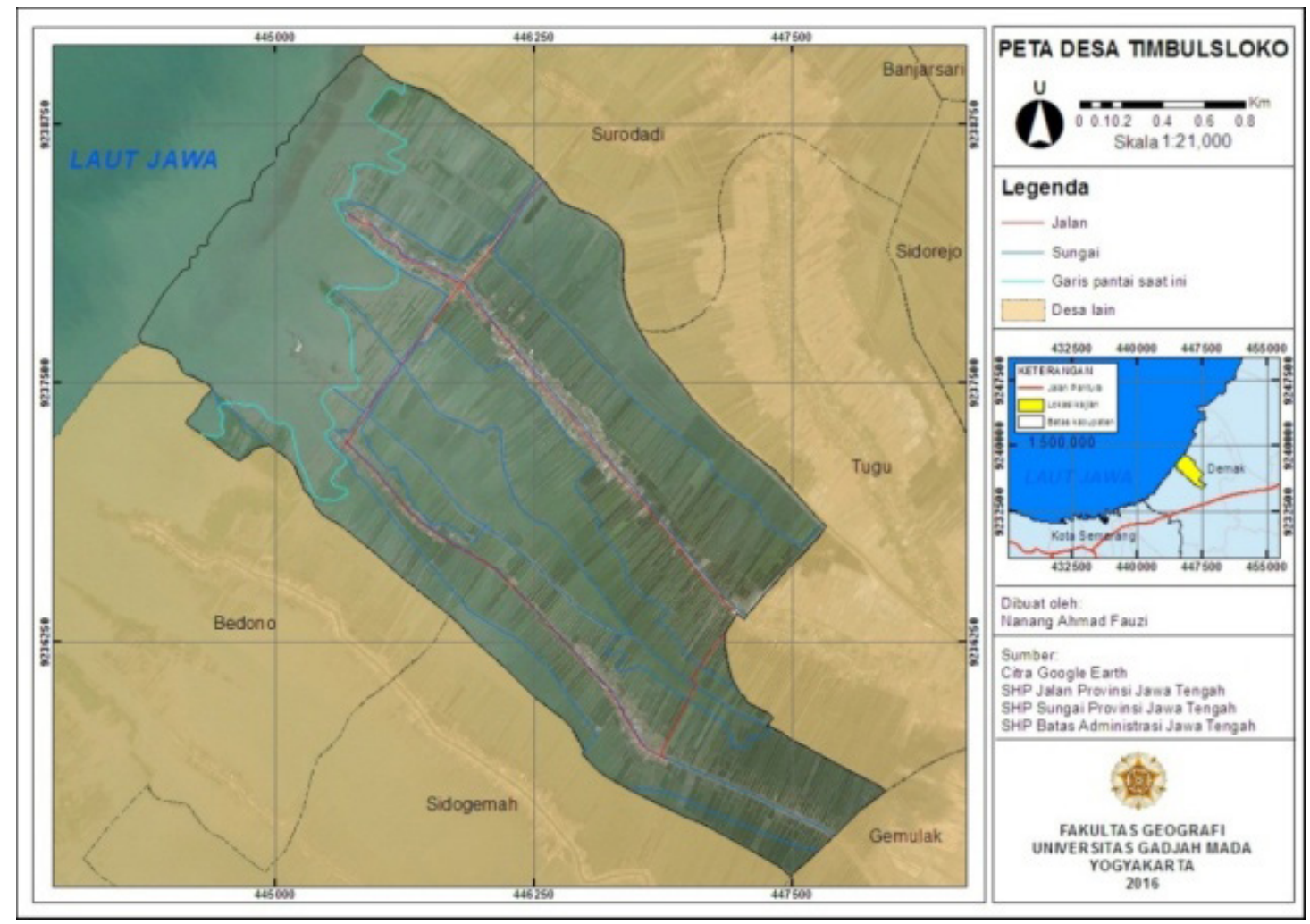

Gambar 1 Peta Administrasi Desa Timbulsloko 
Mobilitas Penduduk, Kemiskinan, dan Ketahanan Pangan di Daerah Bencana:

Kasus Desa Timbulsloko, Kecamatan Sayung, Kabupaten Demak, Provinsi Jawa Tengah

\section{Hasil Penelitian}

\section{Kondisi Daerah Penelitian}

Kecamatan Sayung merupakan salah satu Kecamatan yang termasuk dalam wilayah administratif Kabupaten Demak, Jawa Tengah. Luas wilayah Kecamatan Sayung secara keseluruhan adalah sekitar $78,69 \mathrm{~km} 2$ atau 11 persen dari total luas keseluruhan Kabupaten Demak (BPS Demak, 2009). Banjir rob merupakan salah satu fenomena efek dari terjadinya pemanasan global. Kabupaten Demak merupakan salah satu daerah yang terkena banjir rob sejak tahun 1980-an. Sebagaimana telah disebutkan, banjir rob memiliki intensitas kejadian dan tingkat keparahan yang semakin tinggi dengan lama genangan 6-8 jam setiap harinya. Kecamatan Sayung merupakan daerah yang terkena dampak paling parah dari banjir rob yang terjadi secara rutin di Kabupaten Demak. Terdapat tiga desa terdampak paling parah di Kecamatan Sayung, yaitu Desa Bedono, Timbulsloko, dan Sriwulan. Ketiga desa tersebut merupakan desa yang terletak tepat di sepanjang pantai utara Kabupaten Demak.

Desa Timbulsloko merupakan salah satu desa yang termasuk dalam wilayah administratif Kecamatan Sayung, Kabupaten Demak yang memiliki luas wilayah sekitar $462.5 \mathrm{Ha}$. Desa Timbulsloko merupakan desa di daerah pesisir Kabupaten Demak yang berbatasan langsung dengan Laut Jawa di sebelah barat, yang kemudian menjadikan Timbulsloko mengalami banjir rob setiap tahun. Data dari BMKG Semarang 2013 dan 2014 menunjukkan bahwa tinggi gelombang cukup tinggi pada Januari sampai dengan Maret sehingga terjadi musim barat dan arah gelombang menuju ke arah barat yang mengakibatkan kecamatan yang berbatasan langsung dengan Laut Jawa di sebelah barat tergerus oleh gelombang pada musim barat dan musim peralihan. Tidak hanya itu, kecepatan arus pada musim timur mengarah ke arah barat dengan cukup tinggi dan dapat menyebabkan sedimentasi serta dapat pula menggerus daratan di Kecamatan Sayung. Penggerusan daratan dan sedimentasi ini turut mengubah garis pantai yang ada di pesisir utara Jawa, termasuk yang terjadi di Desa Timbulsloko. Kondisi tersebut memengaruhi perkembangan dan perubahan penggunaan lahan yang ada di desa tersebut.

Jumlah penduduk di Desa Timbulsloko saat penelitian adalah 3.626 jiwa, yang terdiri atas penduduk laki-laki 1.844 jiwa dan 1.782 jiwa penduduk perempuan. Adapun jumlah rumah tangga di desa penelitian adalah 1.122 yang tersebar di 7 Rukun Warga (RW).

Pendidikan penduduk di desa penelitian dapat dikatakan sangat rendah karena lebih dari 70 persen penduduk berpendidikan kurang dari SD. Satu hal penting yang perlu dicatat adalah penduduk di Desa Timbulsloko tidak lagi tergantung pada sektor pertanian. Hal ini karena potensi pertanian di desa tersebut dapat dikatakan telah habis terkena dampak banjir rob yang berlangsung secara rutin tiap tahun. Hasil observasi menunjukkan bahwa sebagian besar penduduk menggantungkan hidupnya sebagai buruh pabrik di wilayah Kecamatan Sayung dan wilayah sekitarnya, termasuk Semarang. Hal ini pula yang pada akhirnya menjelaskan pola mobilitas penduduk di lokasi penelitian.

\section{Kemiskinan dan Mobilitas Penduduk}

\section{a. Kemiskinan}

Banjir rob telah mengakibatkan sebagian besar wilayah Desa Timbulsloko tergenang. Selain menggenangi permukiman penduduk dan mengganggu aktivitas sehari-hari, 


\section{Sukamdi}

banjir rob juga mengakibatkan terendamnya lahan tambak sebagai salah satu lapangan pekerjaan yang tersedia di desa. Selain itu, banjir rob juga mengakibatkan hilangnya lahan produktif yang menjadi sumber pangan penduduk desa. Hal ini karena jauh sebelum penduduk banyak memanfaatkan lahan desa sebagai tambak, lahan di Desa Timbulsloko juga dimanfaatkan sebagai lahan pertanian sawah. Menurut salah satu responden, sekitar tahun 2002 terjadi perluasan genangan banjir rob yang mengakibatkan air asin masuk ke dalam lahan sawah dan berdampak pada penurunan kesuburan lahan. Penurunan kesuburan disertai banjir rob yang semakin tinggi menjadi alasan penduduk untuk mengubah lahan pertanian sawahnya menjadi lahan tambak.

Meluasnya genangan banjir rob mengakibatkan penurunan kesuburan tanah secara menyeluruh di desa. Saat ini hanya terdapat sedikit jenis tumbuhan yang dapat hidup di desa selain tumbuhan jenis bakau. Selain genangan rob di atas permukaan tanah, intrusi air asin juga terjadi di bawah permukaan tanah. Akibatnya, praktis pemenuhan kebutuhan pangan di desa saat ini bergantung pada pasokan dari daerah lain. Hal ini berbeda dibandingkan dengan saat lahan pertanian sawah masih dapat diolah. Menurut salah satu responden, kebutuhan pangan saat itu dapat dipenuhi dari aktivitas pertanian yang berlangsung di desa. Selain kebutuhan pangan pokok, terdapat komoditas umbi-umbian maupun buah-buahan yang dapat tumbuh dan dapat diambil tanpa mengeluarkan biaya. Adapun selain masalah kemampuan menyediakan pangan, dampak umum banjir rob yang paling dirasakan warga meliputi kendala aksesibilitas jalan, kendaraan menjadi mudah rusak, serta peningkatan harga barang.

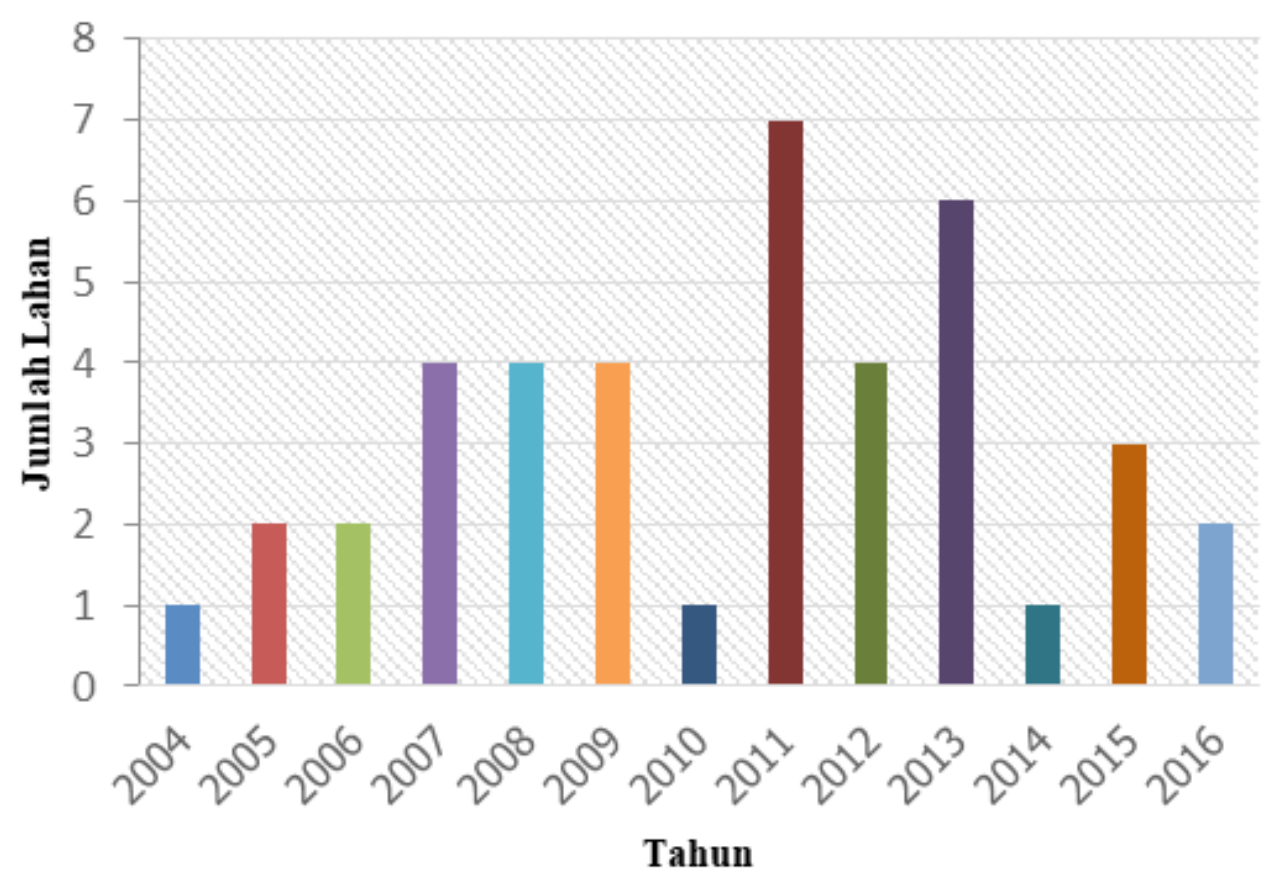

Sumber: Hasil Olah Data Primer, 2016

Gambar 2 Jumlah Lahan Milik Responden yang Tergenang Banjir Rob menurut Tahun 
Gambar 2 menunjukkan jumlah lahan tergenang milik responden paling banyak tergenang pada 2011 atau sekitar delapan tahun yang lalu. Banjir rob sebenarnya telah mulai menggenangi wilayah desa sejak tahun 1990-an dan menjadi semakin parah tahun 2000-an karena semakin banyak lahan produktif milik masyarakat yang tergenang. Adapun lahan produktif yang tergenang oleh banjir rob teridentifikasi dalam dua jenis, yaitu sawah dan tambak. Lahan produktif tambak merupakan lahan produktif yang sebagian besar tergenang oleh banjir rob.

Banjir rob mulai dirasakan sangat mengganggu aktivitas tambak sekitar tahun 2010. Sebelum terganggu oleh banjir rob, aktivitas tambak di Desa Timbulsloko merupakan lapangan pekerjaan yang potensial dan dapat menjadi sumber penghasilan yang mencukupi. Dengan komoditas bandeng dan udang, rata-rata dapat diperoleh 2-3 kw dari setiap sekali panen per 1 ha lahan tambak. Terendamnya lahan tambak oleh banjir rob yang semakin tinggi, selain merusak areal tambak juga menimbulkan kerugian karena bibit bandeng dan udang yang disebar menghilang.

Pada Tabel 1 terlihat bahwa diperkirakan kerugian yang dialami petani, baik sawah, tambak bandeng, dan tambak udang mencapai nilai yang cukup besar. Dapat dilihat bahwa saat kondisi masih normal atau belum tergenang banjir rob, petani tambak udang mampu menghasilkan rata-rata $\mathrm{Rp}$ 47.500,00 (mendekati Rp 50.000,00) setiap panen atau setiap harinya. Sementara itu, bagi petani tambak bandeng, diperkirakan rata-rata kerugian yang harus ditanggung juga tidak kalah besarnya. Rata-rata kerugian yang dialami oleh petani tambak bandeng sekitar Rp 6.370.000,00 per panen atau setiap 5-6 bulan sekali. Kerugian dan prospek usaha yang menurun mengakibatkan penduduk meninggalkan usaha tambaknya. Kerugian yang harus ditanggung dan dihadapi oleh para petani tambak maupun sawah berdampak pada pemenuhan kebutuhan sehari-harinya. Diketahui bahwa tempat usaha yang ada memiliki dua kegunaan, yaitu sebagai sumber penghasilan utama atau tambahan (hasil panen dijual) dan juga berguna untuk dimanfaatkan sendiri dalam memenuhi kebutuhan pangan yang ada. Terendamnya lahan produktif, baik tambak maupun sawah, di desa ini juga merupakan salah satu sumber membengkaknya pengeluaran rumah tangga yang ada. Hasil tambak maupun sawah yang dulu dapat dimanfaatkan langsung untuk pemenuhan pangan kini harus dipenuhi dengan cara membeli atau mengalokasikan pendapatan rumah tangga untuk membeli pangan tersebut.

Hasil wawancara menunjukkan tidak banyak ditemukan penduduk yang bekerja sebagai petani tambak sebelum bekerja pada pekerjaan saat ini. Namun, terendamnya

\section{Tabel 1 Estimasi Rata-Rata Kerugian Akibat Rob per Panen (dalam Rupiah)}

Jenis Lahan Produktif

Tambak Bandeng

Tambak Udang

Sawah Padi

Sumber: Hasil Olah Data Primer, 2016
Estimasi Rata-Rata Kerugian Akibat Rob per Panen (Rp)

$\begin{array}{lr}\text { per } 5-6 \text { bulan } & 6,370,000 \\ \text { per hari } & 47,500 \\ \text { per } 4 \text { bulan } & 1,350,000\end{array}$


tambak oleh banjir rob merupakan alasan utama penduduk memilih untuk berganti pekerjaan di luar usaha tambak. Untuk kepala keluarga/suami, umumnya mereka memilih bekerja sebagai pedagang dan buruh bangunan meskipun mengaku mengalami penurunan penghasilan. Sementara itu, bagi istri, umumnya mereka tidak memiliki pekerjaan lain atau menjadi ibu rumah tangga. Status istri yang kemudian tidak memiliki pekerjaan, selain dimungkinkan untuk lebih memperhatikan mengurus keluarga juga dapat disebabkan oleh sedikitnya peluang usaha yang tersedia di desa. Hasil wawancara menunjukkan mayoritas responden tidak mengetahui atau menyatakan tidak ada peluang usaha yang mudah diperoleh di daerah asal (desa penelitian). Sementara itu, sedikit lainnya mengatakan menangkap ikan atau kepiting dan berdagang sebagai peluang usaha yang mudah diperoleh.

Banjir rob sedikit banyak turut berpengaruh terhadap pilihan jenis pekerjaan sebagian besar penduduk Desa Timbulsloko saat ini. Keterbatasan lahan menyebabkan penduduk Desa Timbulsloko yang berganti pekerjaan maupun yang baru bekerja memilih bekerja di sektor manufaktur maupun konstruksi dibandingkan dengan di sektor pertanian. Hal ini dapat dicerminkan dari jenis pekerjaan kepala keluarga dari setiap rumah tangga di Desa Timbulsloko. Hasil wawancara terhadap 100 rumah tangga menunjukkan sebagian besar kepala keluarga bekerja sebagai buruh, baik buruh pabrik maupun buruh bangunan. Pilihan pekerjaan tersebut juga tidak lepas dari faktor keberadaan pabrik-pabrik di Kecamatan Sayung dan sekitarnya serta kedekatan jarak dengan Kota Semarang.

Banyaknya penduduk yang memilih bekerja sebagai buruh, selain didukung oleh ketersediaan lapangan pekerjaan dapat, juga disebabkan oleh tingkat pendidikan yang rendah. Dengan tingkat pendidikan kepala keluarga yang mayoritas SD/MI/ sederajat, sulit mengharapkan pekerjaan yang membutuhkan tingkat keterampilan khusus. Menjadi buruh dengan upah yang disetarakan UMR Kabupaten Demak merupakan hal yang paling memungkinkan. Akan tetapi, ke depan dimungkinkan untuk terjadi perubahan tren jenis pekerjaan mengingat perhatian terhadap tingkat pendidikan anak yang semakin tinggi, yaitu rata-rata telah sampai jenjang SMP/ MTs/sederajat, bahkan SMA/MA/sederajat. Hal ini diharapkan dapat meningkatkan keterampilan kerja sehingga dapat memperoleh kesempatan kerja yang lebih luas serta penghasilan yang lebih baik.

Kualitas rumah tangga tidak hanya dilihat dari kualitas dan tingkat penghasilan kepala keluarga, tetapi juga kemampuan rumah tangga tersebut untuk memenuhi kebutuhannya. Besar pengeluaran untuk pemenuhan kebutuhan tersebut dibandingkan dengan garis kemiskinan untuk mengetahui apakah rumah tangga tersebut tergolong rumah tangga miskin atau tidak.

Jika diukur dari garis kemiskina di Kabupaten Demak, hasil penelitian menunjukkan bahwa angka kemiskinan tercatat 22 persen. Garis kemiskinan Kabupaten Demak untuk pengukuran ini adalah angka estimasi karena ketiadaan data garis kemiskinan yang secara spesifik mengacu pada desa yang bersangkutan. Dengan pertimbangan garis kemiskinan Kabupaten Demak yang selalu berada di atas garis kemiskinan Provinsi Jawa Tengah, diasumsikan bahwa peningkatan garis kemiskinan Kabupaten Demak setara dengan peningkatan garis kemiskinan Provinsi Jawa Tengah. Dengan demikian, diperoleh garis kemiskinan Kabupaten Demak sebesar Rp $351.348,00$. 
Mobilitas Penduduk, Kemiskinan, dan Ketahanan Pangan di Daerah Bencana:

Kasus Desa Timbulsloko, Kecamatan Sayung, Kabupaten Demak, Provinsi Jawa Tengah

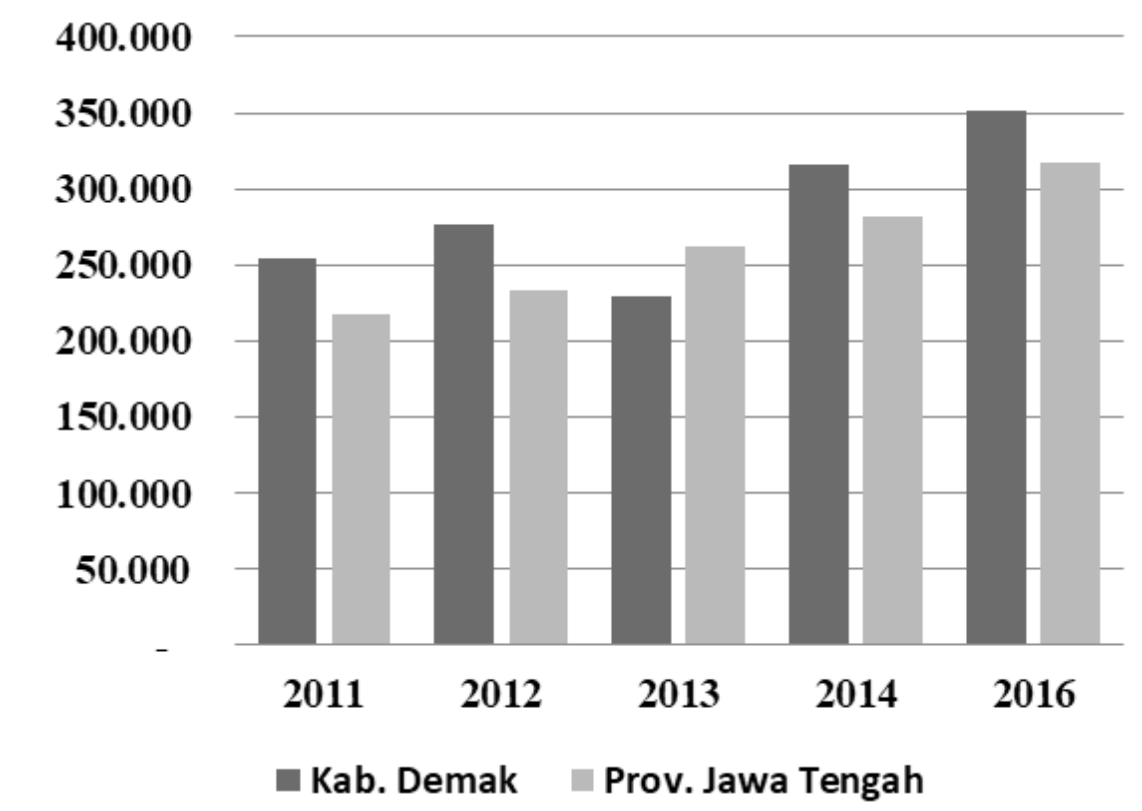

Sumber: website BPS Provinsi Jawa Tengah

\section{Gambar 3 Grafik Garis Kemiskinan Kabupaten Demak dan Provinsi Jawa Tengah 2011-2016}

Pengukuran pengeluaran pemenuhan kebutuhan per kapita terdiri atas pengeluaran kebutuhan untuk makanan dan bukan makanan. Berdasarkan data keseluruhan rumah tangga, diperoleh proporsi pengeluaran untuk makanan sebesar 67,48 persen, sedangkan proporsi pengeluaran bukan makanan sebesar 32,52 persen. Proporsi pengeluaran untuk makanan pada rumah tangga miskin cenderung lebih tinggi sebesar 78,96 persen dibandingkan dengan pada rumah tangga tidak miskin yang sebesar 64,24 persen. Sementara itu, proporsi pengeluaran bukan makanan pada rumah tangga miskin lebih rendah, yaitu sebesar 21,04 persen dibandingkan dengan pada rumah tangga tidak miskin 35,76 persen. Hal ini menunjukkan konsentrasi pengeluaran untuk makanan bagi rumah tangga miskin cenderung lebih besar dibandingkan dengan rumah tangga tidak miskin.
Berdasarkan penjelasan tersebut di atas, maka dapat disimpulkan bahwa banjir rob memiliki dampak negatif terhadap perekonomian penduduk. Di satu pihak hilangnya lahan pertanian telah menyebabkan hilangnya mata pencaharia penduduk dan hal tersebut menyebabkan ekonomi penduduk juga mengalami degradasi. Angka kemiskinan sebesar 22 persen merupakan angka yang lebih tinggi daripada rata-rata nasional. Pertanyaan penting yang menarik adalah apakah kondisi tersebut memiliki kaitan dengan pola mobilitas penduduk?

\section{b. Pola Mobilitas Penduduk}

Fenomena mobilitas penduduk merupakan fenomena umum yang dapat ditemukan di berbagai wilayah di seluruh dunia, tidak terkecuali dapat ditemukan di lokasi penelitian, yaitu Desa Timbulsloko, Kabupaten Demak. 


\section{Sukamdi}

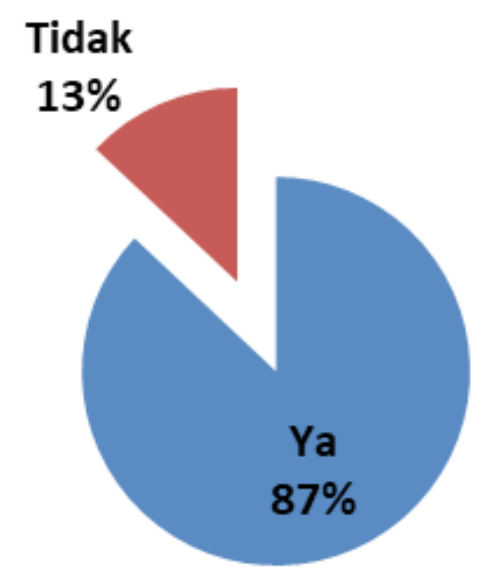

Sumber: Hasil Olah Data Primer, 2016

\section{Gambar 4 Kepala Rumah Tangga dan Aktivitas Mobilitas}

Hasil penelitian menunjukkan bahwa dari 411 anggota rumah tangga responden, terdapat sekitar 45,01 persen atau berjumlah 185 jiwa melakukan mobilitas dalam berbagai bentuk dan motif. Atau dengan kata lain, rata-rata terdapat dua anggota rumah tangga di setiap rumah tangga yang melakukan mobilitas.

Angka ini sejalan dengan asumsi bahwa mobilitas penduduk dapat digunakan sebagai jalan ke luar untuk mengatasi permasalahan ekonomi yang diakibatkan oleh banjir rob. Angka ini dikonfirmasi dengan data kepala rumah tangga yang melakukan mobilitas penduduk. Seperti terlihat dalam Gambar 4, sebanyak 87 persen kepala rumah tangga melakukan mobilitas.

Hal menarik yang perlu untuk dikaji adalah tujuan dan daerah tujuan mobilitas penduduk yang dilakukan oleh penduduk. Tabel 2, 3, dan 4 memberikan penjelasannya.
Tabel 2 menunjukkan bahwa terdapat setidaknya tiga alasan melakukan mobilitas, yaitu bekerja, sekolah/mondok/kuliah, dan lainlain (mengantar anak sekolah dan berkunjung). Tabel 2 juga menjelaskan bahwa alasan utama melakukan mobilitas adalah bekerja. Hal ini sekaligus menegaskan bahwa motif mobilitas penduduk adalah ekonomi. Jika dikaitkan dengan penjelasan sebelumnya, maka hal ini juga menegaskan bahwa mobilitas penduduk adalah cara untuk mengatasi masalah hilangnya pekerjaan di desa akibat banjir rob.

Kemana mereka melakukan mobilitas? Ada fenomena menarik terkait dengan tujuan mobilitas. Tabel 3 memperlihatkan bahwa sebagian besar penduduk melakukan mobilitas ke desa-desa di dalam Kecamatan Sayung. Namun, jumlah yang melakukan mobilitas penduduk ke Kota Semarang juga

Tabel 2 Bentuk Kegiatan yang Dilakukan Selama Mobilitas

\begin{tabular}{lcc}
\hline Kegiatan Mobilitas & Jumlah (jiwa) & \% \\
\hline Bekerja & 150 & 81.1 \\
Sekolah/Mondok/Kuliah & 28 & 15.1 \\
Lain-Lain & 7 & 3.8 \\
Total & $\mathbf{1 8 5}$ & $\mathbf{1 0 0}$ \\
\hline
\end{tabular}

Sumber: Hasil Olah Data Primer, 2016 
Mobilitas Penduduk, Kemiskinan, dan Ketahanan Pangan di Daerah Bencana:

Kasus Desa Timbulsloko, Kecamatan Sayung, Kabupaten Demak, Provinsi Jawa Tengah

Tabel 3 Daerah Tujuan Melakukan Mobilitas

\begin{tabular}{lrr}
\hline \multicolumn{1}{c}{ Daerah Tujuan Melakukan Mobilitas } & $\begin{array}{c}\text { Jumlah } \\
\text { (jiwa) }\end{array}$ & \% \\
\hline Desa dalam Kecamatan Sayung & 79 & 42.7 \\
Kecamatan Lain dalam Kabupaten Demak & 23 & 12.4 \\
Luar Kabupaten Demak dalam Provinsi Jateng (selain Kota & 4 & 2.2 \\
Semarang) & 66 & 35.7 \\
Kota Semarang & 12 & 6.5 \\
Luar Provinsi Jawa Tengah & 1 & 0.5 \\
Luar Negeri & $\mathbf{1 8 5}$ & $\mathbf{1 0 0 . 0}$ \\
Total & & \\
\hline
\end{tabular}

Sumber : Hasil Olah Data Primer, 2016

*) Catatan : pertanyaan tentang mobilitas penduduk ditanyakan

ke semua anggota rumah tangga

sangat tinggi, yaitu hampir 36 persen. Hukum Ravenstein yang mengaitkan antara jarak dengan migrasi terbantahkan. Benar bahwa jarak menjadi pertimbangan bagi sebagian penduduk dalam melakukan mobilitas, tetapi ada indikasi bahwa jarak tidak lagi menjadi pertimbangan untuk penduduk yang lain.

Jika sebagian besar penduduk melakukan mobilitas dalam rangka bekerja (motif ekonomi), apakah tujuannya juga memiliki pola yang sama dengan tujuan mobilitas pada umumnya? Tabel 4 menunjukkan hal tersebut.
Table 4 memperlihatkan bahwa Kota Semarang merupakan daerah yang menjadi tujuan utama penduduk Desa Tmbulsloko untuk bekerja. Dengan hasil ini, maka dapat disimpulkan bahwa untuk tujuan bekerja, jarak tidak menjadi pertimbangan. Akan tetapi, juga perlu diperhatikan bahwa terdapat sepertiga penduduk yang bekerja di desa di dalam kecamatan yang sama. Data ini sekaligus menunjukkan bahwa ketersediaan pekerjaan tersegmentasi ke dalam dua wilayah, yaitu desa-desa di Kecamatan Sayung dan Kota Semarang.

\section{Tabel 4 Daerah Tujuan Bekerja}

\begin{tabular}{lrr}
\hline \multicolumn{1}{c}{ Daerah Tujuan Bekerja } & $\begin{array}{c}\text { Jumlah } \\
\text { (jiwa) }\end{array}$ & \multicolumn{1}{c}{$\%$} \\
\hline Desa dalam Kecamatan Sayung & 50 & 33.3 \\
Kecamatan Lain dalam Kabupaten Demak & 20 & 13.3 \\
Luar Kabupaten Demak dalam Provinsi Jateng (selain Kota & 4 & 2.7 \\
Semarang) & 65 & 43.3 \\
Kota Semarang & 10 & 6.7 \\
Luar Provinsi Jawa Tengah & 1 & 0.7 \\
Luar Negeri & $\mathbf{1 5 0}$ & $\mathbf{1 0 0}$ \\
Total & & \\
\hline
\end{tabular}

Sumber : : Hasil Olah Data Primer, 2016

*) Catatan : pertanyaan tentang mobilitas penduduk ditanyakan

ke semua anggota rumah tangga 


\section{Sukamdi}

Kota Semarang sebagai ibu kota Provinsi Jawa Tengah merupakan ibu kota Provinsi Jawa Tengah yang menjadi pusat segala kegiatan, seperti pusat pemerintahan, pusat pelayanan, hingga pusat perekonomian. Tidak aneh bahwa banyak penduduk yang pergi ke Kota Semarang untuk mengadu nasib. Hal tersebut dipertegas oleh data yang lain yang menunjukkan bahwa seseorang melakukan mobilitas penduduk ke daerah tertentu karena kesempatan kerja di daerah tujuan lebih banyak (Tabel 5). Kecenderungan ini sekaligus juga merupakan ilustrasi dari intensifnya mobiitas penduduk dari desa ke kota dibandingkan dengan dari desa ke desa.

Sebagaimana telah dijelaskan pada bagian sebelumnya, banjir rob telah menghilangkan kesempatan kerja di sektor pertanian. Penduduk terdesak untuk mencari pekerjaan di luar desa, terutama Kota Semarang, karena kesempatan kerja khususnya di luar pertanian lebih terbuka.

Bagi penduduk yang masih terikat dengan sektor pertanian yang tersisa di Desa Timbulsloko, mereka menggantungkan hidupnya pada pekerjaan sebagai nelayan atau pencari ikan atau kepiting. Namun, pekerjaan tersebut dalam banyak kasus tidak dijadikan sebagai tumpuan hidup karena mereka tetap mencari pekerjaan di luar sektor pertanian.

Keterlibatan penduduk desa yang bekerja di Kota dapat juga dijelaskan dari teori yang dikemukakan oleh Todaro (BKKBN, 2012). Teori ini menjelaskan bahwa keputusan seseorang untuk melakukan mobilitas ditentukan oleh nilai-nilai faktor penarik dan faktor pendorong yang dimiliki oleh orang tersebut. Hal ini dapat terjadi karena mobilitas dianggap sebagai bentuk investasi individu yang sebelumnya telah melalui beberapa tahap yang dinamakan sebagai tahap perhitungan biaya dan manfaat oleh individu yang bersangkutan atau calon pelaku mobilitas (BKKBN, 2012).

Skema keputusan bermigrasi menurut model Todaro juga turut menjelaskan proses atau cara mobilitas yang akan terjadi. Model Todaro memasukkan beberapa hal yang dikelompokkan sebagai cost of migration atau biaya migrasi, antara lain, adalah opportunity cost, cost of living, transport cost, dan psychic cost. Keberadaan hal-hal tersebut mengakibatkan pola mobilitas yang terbentuk dalam masyarakat Timbulsloko yang bersifat ulang-alik/harian/commuting.

Hasil penelitian ini menunjukkan bahwa 86 persen mobilitas yang terjadi dilakukan ulang-

\section{Tabel 5 Alasan Melakukan Mobilitas}

\begin{tabular}{lrr}
\hline \multicolumn{1}{c}{ Alasan Melakukan Mobilitas } & Jumlah (jiwa) & \% \\
\hline Mendapatkan Upah Lebih Tinggi & 9 & 4.9 \\
Kesempatan Kerja Lebih Banyak & 83 & 44.9 \\
Lapangan Kerja yang Lebih Sesuai di daerah tujuan & 4 & 2.2 \\
Tuntutan Pekerjaan & 50 & 27.0 \\
Melanjutkan Pendidikan & 28 & 15.1 \\
Lainnya & 11 & 5.9 \\
Total & $\mathbf{1 8 5}$ & $\mathbf{1 0 0}$ \\
\hline
\end{tabular}

Sumber : Hasil Olah Data Primer, 2016

*) Catatan : pertanyaan tentang mobilitas penduduk ditanyakan ke semua anggota rumah tangga 
Mobilitas Penduduk, Kemiskinan, dan Ketahanan Pangan di Daerah Bencana:

Kasus Desa Timbulsloko, Kecamatan Sayung, Kabupaten Demak, Provinsi Jawa Tengah

alik atau harian. Pola mobilitas yang bersifat ulang-alik atau harian dapat menjadi pilihan dari para pelaku mobilitas karena jarak antara Desa Timbulsloko dan Kota Semarang relatif dapat ditempuh dengan transportasi yang tersedia, yaitu sekitar $25 \mathrm{~km}$. Keberadaan kawasan industri Terboyo yang masuk dalam daerah administratif Kota Semarang menjadikan kawasan ini sebagai salah satu tujuan para penglaju yang berasal dari Desa Timbulsloko. Jarak yang dekat atau jarak yang cenderung masih dapat ditoleransi oleh para pelaku mobilitas merupakan salah satu alasan pola mobilitas yang terbentuk bersifat ulang-alik atau harian. Pola mobilitas yang bersifat ulang-alik tersebut kemudian dapat menjelaskan pola pemilihan moda transportasi selama melakukan mobilitas yang didominasi oleh moda transportasi sepeda motor. Hampir 90 persen pelaku mobilitas yang berasal dari Desa Timbulsloko memilih sepeda motor sebagai moda transportasi selama melakukan mobilitas.

Penjelasan lebih lanjut mengenai alasan pola mobilitas yang terbentuk bersifat harian atau ulang-alik menggunakan sepeda motor adalah dengan melakukan mobilitas tersebut. maka cost of migration dapat diperkecil. Melakukan mobilitas menuju daerah yang berjarak dekat dengan tempat tinggal dianggap merupakan keputusan paling rasional bagi masyarakat Timbulsloko. Kondisi daerah asal yang semakin menawarkan kesempatan kerja yang sempit mengharuskan masyarakat untuk mencari kerja di tempat yang lebih baik dalam berbagai hal, termasuk di dalamnya kesempatan kerja dan tingkat upah yang lebih tinggi. Desakan ekonomi yang harus dihadapi oleh masyarakat Timbulsloko menjadi faktor pendorong bagi pelaku mobilitas atau penglaju ke Kota Semarang. Penilaian akan faktor pendorong dan penarik mobilitas yang ada diikuti pula dengan perhitungan biaya yang harus dikeluarkan oleh pelaku mobilitas. Kota Semarang dianggap sebagai daerah dengan cost of migration yang dapat ditoleransi karena jarak yang dekat dapat memperkecil opportunity cost dan transport cost serta meniadakan biaya yang harus dikeluarkan terkait dengan cost of living. Pola mobilitas harian atau ulang-alik juga mampu memperkecil psychic cost yang harus ditanggung selama mobilitas berlangsung. Dengan melakukan mobilitas harian atau ulang-alik. pelaku mobilitas masih dapat bersosialisasi dengan lingkungan sekitar sehingga social adjustment negatif yang akan muncul dapat diperkecil atau bahkan ditiadakan.

\section{c. Keinginan untuk Pindah secara Permanen}

Pembahasan sebelumnya dilakukan untuk mengetahui karakteristik mobilitas yang terbentuk dalam masyarakat Timbulsloko, termasuk di dalamnya motif, daerah tujuan, pola, dan moda transportasi selama mobilitas.

Mempertimbangkan bahwa lokasi penelitian merupakan daerah yang setiap hari terendam rob, maka isu pindah atau migrasi secara permanen merupakan bahasan yang menarik. Hasil penelitian menunjukkan bahwa 59 persen pelaku mobilitas menyatakan tidak ingin pindah dari Timbulsloko, sedangkan 41 persen lainnya menyatakan ingin pindah dari Timbulsloko.

Everett S. Lee (2000) mengemukakan bahwa terdapat empat faktor yang dapat memengaruhi migrasi, yaitu faktor pendorong, faktor penarik, rintangan antara, dan faktor individu. Everett S. Lee menekankan bahwa faktor individu adalah faktor terpenting yang dapat memengaruhi migrasi. Menurut Robert Noris (dalam Mantra 2000), diagram Lee perlu ditambah dengan tiga komponen. yaitu migrasi kembali, kesempatan antara, dan migrasi 
Tabel 6 Alasan Ketidakinginan Pindah secara Permanen

\begin{tabular}{lc}
\hline \multicolumn{1}{c}{ Alasan Ketidakinginan Pindah Permanen } & $\%$ \\
\hline Faktor Keterbatasan Dana & 29 \\
Faktor Keterbatasan Kepemilikan Lahan & 15 \\
Faktor Keluarga dan Tanah Kelahiran & 36 \\
Faktor Pekerjaan yang Dimiliki saat ini & 7 \\
Faktor Keberadaan Bantuan Pemerintah & 5 \\
Lain-Lain & 8 \\
\hline
\end{tabular}

Sumber: Hasil Olah Data Primer, 2016

paksaan (force migration), sebagaimana yang telah dikemukakan pada bagian sebelumnya. Sementara itu, Noris berpendapat bahwa faktor daerah asal adalah faktor terpenting. Istilah bilocal population sering kali dikaitkan dengan fenomena mobilitas atau migrasi di suatu daerah. Hal tersebut jelas terlihat pada Tabel 6 yang memperlihatkan faktor keluarga dan tanah kelahiran merupakan faktor tertinggi yang menyebabkan masyarakat Timbulsloko tidak ingin pindah secara permanen dari tempat tinggal sekarang. Hubungan kekerabatan atau social system yang sangat erat berlaku dalam masyarakat Desa Timbulsloko bukan merupakan fenomena asing dan dapat ditemui di berbagai daerah perdesaan di seluruh Indonesia. Sistem sosial yang cukup kuat di perdesaan dapat turut menentukan keputusan individu atau calon pelaku mobilitas. Sistem sosial kekeluargaan yang erat dengan rasa ingin terus dalam kebersamaan di segala kondisi juga berlaku dalam masyarakat Desa Timbulsloko. Hal itu yang kemudian menjadi salah satu faktor penting yang dapat mempertahankan niat individu untuk melakukan migrasi atau pindah permanen dari desa tersebut.

Selain faktor keluarga dan tanah kelahiran, tampaknya faktor keterbatasan dana merupakan faktor penting lainnya yang harus diperhatikan lebih lanjut. Beberapa temuan di lapangan, baik pada responden yang menyatakan ingin maupun tidak ingin untuk melakukan migrasi atau pindah secara permanen dari Desa Timbulsloko, menemukan hal tersebut. Faktor keterbatasan dana merupakan salah satu hal yang dapat bersifat sebagai rintangan dan dapat menghambat, bahkan membatalkan niat individu untuk melakukan migrasi, baik secara permanen ataupun tidak. Hal ini menandakan sebenarnya desakan kondisi lingkungan telah membuat toleransi yang dimiliki oleh masyarakat Desa Timbulsloko terhadap bencana yang ada sedikit menurun. Namun, kembali lagi ketika masyarakat harus dihadapkan dengan faktor keterbatasan dana, maka kondisi tidak berdaya yang berlaku dan terjadi.

Tabel 7 menunjukkan hal yang berbeda dengan pembahasan sebelumnya karena terdapat dua alasan masyarakat Timbulsloko memiliki keinginan untuk pindah secara permanen. Alasan berupa perasaan terganggu, tidak nyaman, dan penilaian masyarakat mengenai desa yang tidak lagi layak huni merupakan alasan dominan yang melatarbelakangi keinginan masyarakat Timbulsloko untuk pindah. Menghadapi kondisi rumah dan lahan tergenang oleh banjir rob setiap harinya membuat masyarakat Timbulsloko merasa terganggu dan tidak nyaman. Banjir rob yang setiap hari terus menggenangi jalan, rumah, maupun lahan milik masyarakat Timbulsloko menimbulkan gangguan terhadap jalannya 
Mobilitas Penduduk, Kemiskinan, dan Ketahanan Pangan di Daerah Bencana:

Kasus Desa Timbulsloko, Kecamatan Sayung, Kabupaten Demak, Provinsi Jawa Tengah

Tabel 7 Alasan Keinginan Pindah secara Permanen

\begin{tabular}{lc}
\hline Alasan Keinginan Pindah Permanen & $\%$ \\
\hline Ingin Merasakan Kehidupan yang Lebih Baik & 37 \\
Perasaan Terganggu/Ketidaknyamanan/Ketidaklayakan & 61 \\
Lain-Lain (berkaitan dengan jarak dengan tempat kerja) & 2 \\
Total & $\mathbf{1 0 0}$ \\
\hline
\end{tabular}

Sumber: Hasil Olah Data Primer, 2016

aktivitas ekonomi, pendidikan, dan lainnya. Keinginan untuk mendapatkan kehidupan yang lebih baik menjadi alasan lain bagi masyarakat Timbulsloko memiliki keinginan untuk migrasi atau pindah secara permanen. Adapun kehidupan yang lebih baik yang dimaksudkan dalam hal ini berkaitan dengan kesempatan kerja yang lebih luas dengan upah yang tetap tiap bulannya, kondisi permukiman yang lebih baik, dan pendidikan yang lebih baik anak.

\section{d. Pemenuhan Kebutuhan Pangan}

Ada dua alasan perlunya dibahas pemenuhan kebutuhan pangan. Pertama, pengeluaran untuk pangan memiliki proporsi di atas 60 persen dari total pengeluaran penduduk. Hal ini yang kemudian menyebabkan isu tentang pemenuhan kebutuhan pangan menjadi isu yang menarik untuk dibahas. Jika pemenuhan kebutuhan pangan terganggu, maka secara ekonomi akan menyebabkan penduduk di Desa Timbulsloko mengalami permasalahan yang lebih sulit.

Kedua, banjir rob merupakan bencana yang dapat membuat masyarakat tidak berdaya di segala keadaan, khususnya dengan hilangnya sumber daya pangan. Hal ini akan memengaruhi cara pemenuhan kebutuhan pengan penduduk setempat.
Dalam penelitian ini, fokus pembahasan terhadap pemenuhan kebutuhan pangan adalah pada pemenuhan kebutuhan beras secara kuantitatif. Beras dipilih sebagai fokus karena beras merupakan kebutuhan pokok pangan yang harus terpenuhi. Sementara itu, aspek kualitatif sengaja diabaikan karena aspek kualitatif hanya menjadi penting ketika aspek kuantitatif terpenuhi.

Banjir rob bukan hanya memberikan dampak negatif terhadap sarana dan prasarana, tetapi juga terhadap lahan milik masyarakat, termasuk di dalamnya menggenangi lahan produktif milik masyarakat. Di satu sisi tergenangnya lahan produktif masyarakat akan menyebabkan terganggunya produksi pangan. Tabel 9 menunjukkan perkiraan kebutuhan beras bagi penduduk Desa Timbulsloko. Total kebutuhan beras penduduk Desa Timbulsloko per bulan diperoleh $29,588.82 \mathrm{~kg}$ atau sekitar 29 ton per bulan. Angka tersebut menunjukkan besar ketersediaan beras yang harus dipenuhi agar desa secara sederhana dapat dikatakan memiliki kemandirian pangan. Namun, ketiadaan lahan pertanian sawah yang dapat dimanfaatkan mengakibatkan pemenuhan kebutuhan beras perlu dipasok dari daerah lain. Ketergantungan kebutuhan beras dari daerah lain, selain merugikan dari sisi harga beras yang lebih tinggi, juga menunjukkan ketidaklayakan desa untuk dihuni. 
Tabel 8 Estimasi Kebutuhan Pangan (Beras) Desa Timbulsloko

\begin{tabular}{lr}
\hline Total pengeluaran beras $(\mathbf{k g})$ & $\mathbf{8 1 3 , 7 7}$ \\
\hline Rata-rata kebutuhan beras perkapita perbulan (kg/kapita/bulan) & 8,14 \\
Total kebutuhan beras desa perbulan (kg/bulan) & $29.588,82$ \\
\hline
\end{tabular}

Sumber: Hasil Olah Data, 2016

Hasil wawancara menunjukkan bahwa rata-rata masyarakat Desa Timbulsloko harus mengeluarkan uang sebesar Rp9.550,00 untuk membeli beras $1 \mathrm{~kg}$. Sebagaimana dikutip dari Tribun Jateng 2015, harga beras di pasaran Kabupaten Demak berkisar pada harga Rp9.000,00/kg. Terdapat selisih harga lebih tinggi yang harus dikeluarkan oleh masyarakat Desa Timbulsloko untuk dapat memenuhi kebutuhan pangan berupa beras. Masyarakat Desa Timbulsloko kemudian dihadapkan dengan himpitan pengeluaran pangan yang lebih mahal dan juga kebutuhan-kebutuhan lain yang juga mendesak, salah satunya terkait dengan kebutuhan menanggulangi dampak banjir rob secara fisik.

Secara sesderhana, setiap rumah tangga dengan rata-rata anggota rumah tangga empat orang harus mengeluarkan uang sebanyak Rp.309.320,00 per bulan. Angka ini hampir sama dengan garis kemiskinan Kabupaten Demak tahun 2016. Dengan kata lain, kurang lebih 25 persen dari total pengeluaran rumah tangga adalah untuk memenuhi kebutuhan beras. Pada dasarnya kebutuhan $8,14 \mathrm{~kg} / \mathrm{kapita} /$ bulan tergolong tinggi. Rata-rata kebutuhan beras per rumah tangga secara nasional berkisar antar $4-5 \mathrm{~kg} /$ kapita/bulan.

Apakan kaitannya dengan isu yang dibahas sebelumnya, yaitu mobilitas penduduk dan kemiskinan? Pemenuhan kebutuhan pangan (penduduk) yang relatif tinggi telah menyebabkan permasalahan kemiskinan di Desa Timbulsloko menjadi semakin parah.
Mobilitas penduduk merupakan alternatif untuk "keluar" dari kemiskinan tersebut karena banjir rob telah menghikangkan sumber mata pencaharian. Hal ini sekaligus juga menunjukkan ketergantungan penduduk terhadap "daerah" lain dalam memenuhi kebutuhan ekonomi. Dapat dikatakan bahwa pekerjaan di Kota Semarang dan desa-desa di Kecamatan Sayung menjadi safety belt bagi penduduk Timbulsloko. Sementara itu, untuk pangan (beras), Desa Timbulsloko sangat tergantung pada daerah sekitarnya yang memiliki lahan pertanian yang cukup.

\section{Kesimpulan}

1. Banjir rob di Desa Timbulsloko memiliki dampak ekonomi berganda (multiplyers effect). Di satu pihak banjir rob telah mengakibatkan hilangnya sumber ekonomi penduduk, makanan maupun kesempatan kerja dan pada akhirnya memperparah kemiskinan.

2. Tingkatketergantungan ekonomi penduduk Desa Timbulsloko terhadap daerah di sekitarnya dan bahkan Kota Semarang menjadi sangat tinggi. Hal ini jika tidak di atasi akan menyebabkan persoalan yang lebih serius bagi penduduk.

3. Mobilitas penduduk merupakan cara yang dipilih oleh penduduk sebagai jalan ke luar dari permasalahan yang ada. Hal yang menarik adalah sebagian besar penduduk tidak ingin "pindah" dari Desa Timbulsloko. Isu ini menarik untuk dikaji lebih lanjut karena alasan 
Mobilitas Penduduk, Kemiskinan, dan Ketahanan Pangan di Daerah Bencana:

Kasus Desa Timbulsloko, Kecamatan Sayung, Kabupaten Demak, Provinsi Jawa Tengah

utama mereka adalah keterikatan dengan keluarga dan daerah asal. Hal ini sekaligus mempertegas konsep bilocal population dalam teori migrasi.

4. Penelitian ini juga mempertegas tentang tidak berlakunya hukum Ravenstein bahwa jarak berhubungan dengan migrasi. Untuk motif ekonomi, penduduk dapat menempuh jarak yang jauh demi memenuhi kebutuhannya.

5. Besarnya mobilitas penduduk ke Kota Semarang merupakan bukti tentang intensifikasi arus mobilitas penduduk desa-kota. Hal ini sekaligus sebagai ilustrasi tentang urban bias policy yang memberikan porsi pembangunan lebih besar di kota dan menjadikan kota magnet bagi penduduk perdesaan.

\section{Daftar Pustaka}

Ahyar, M. 2012. Perubahan Iklim. Semarang: Universitas Diponegoro.

Amin, Choirul, Sukamdi, and Rijanta. 2018. "Exploring Typology of Residents Staying in Disaster-Prone Areas: A Case Study in Tambak Lorok, Semarang, Indonesia". Forum Geografi, 32 (1): 24-37.

Badan Meteorologi Klimatologi dan Geofisika (BMKG). 2014. Data Iklim Tahun 20022014 di Kabupaten Demak. BMKG Maritim Semarang.

Bandono, Markus Setio. 2010. "Pengaruh Pendapatan, Penguasaan Lahan, Status Pernikahan, Pendidikan, Jenis Kelamin, Umur, Terhadap Keputusan Tenaga Kerja Menjadi Commuter (Studi kasus Kecamatan Mranggen, Kabupaten Demak)". Skripsi, Semarang: Fakultas Ekonomi Universitas Diponegoro.

BKKBN. 2012. Migrasi dan Urbanisasi di Jabodetabek: Tinjauan Empiris dan Aplikasi Kebijakan. Jakarta: BKKBN.
BPS Kabupaten Demak. 2009. Kabupaten Demak Dalam Angka 2010. Demak: BPS. BPS Kabupaten Demak. 2015. Statistik Daerah Kecamatan Sayung 2015. Demak: BPS.

Desmawan, Bayu Trisna dan Sukamdi. 2012. "Adaptasi Masyarakat Kawasan Pesisir Terhadap Banjir Rob di Kecamatan Sayung, Kabupaten Demak, Jawa Tengah". Jurnal Bumi Indonesia Volume I No.1, Tahun 2012.

FAO. 1996. World Food Summit, 13-17 Nopember 1996. Volume 1, 2 dan 3. FAO, Rome.

Food Agricultural Organization and World Health Organization. 1992. Nutrition and Development, A Global Assesment. Italy: Food Agricultural Organization and World Health Organization.

International Food Policy Research Institute, Washington DCSyngenta. 2014. Rice Bowl Indeks Report. Ricebowlindex.com.

Kementerian Pertanian. 2013. Buletin Konsumsi Pangan, Vol. 4 No. 2, Kementerian Pertanian, Jakarta.

Laporan Desa Timbulsloko Tahun 2015.

Lee, Everett S. 2000. Teori Migrasi. Diterjemahkan oleh Hans Daeng, ditinjau kembali oleh Ida Bagus Mantra. Yogyakarta: Pusat Penelitian Kependudukan Universitas Gadjah Mada.

Mantra, Ida Bagoes. 2000. Demografi Umum. Yogyakarta: Pustaka Pelajar.

Nurhemi, Shinta R.I. Soekro, Guruh Suryani R. 2014. "Pemetaan Ketahanan Pangan Di Indonesia: Pendekatan Tfp Dan Indeks Ketahanan Pangan". Working Paper Jakarta: BI.

Saraswati, Manda Kumoro. 2013. TFP Sektor Pertanian di Indonesia. Diunduh dari Repository.ipb.ac.id pada tanggal 28 Juli 2019. 
The Economist. 2014. Global Food Security Index Report, Foodsecurity.dupont.com.

Thirtle, Colin; Jon Atkins; Paul Bottomley; Nancy Gonese; Jones Govereh. 1993. "Agricultural Productivity in Zimbabwe", The Economic Journal, Vol. 417.

Tribun Jateng. 2015. "Harga Beras di Demak Sudah Turun Jadi Rp 9000 per kilogram". Jateng.tribunnews.com.

Todaro, M.P. \& Smith. 2003. Pembangunan Ekonomi di Dunia Ketiga jilid 1. Jakarta: Erlangga.

Undang-Undang Nomor 25 Tahun 2000 tentang 14 Program Pembangunan Nasional Tahun 2000-2004.

Warr, Peter. 2014. Food Insecurity and Its Determinants. The Australian National University.

Yen, Khoo Choon; Maria Platt, Brenda S.A. Yeoh, Silvia Mila Arlini, Grace Baey, Theodora Lam, Sukamdi, Julie Litchfield and Endang Sugiyarto. 2014. "Gendered Migration Patterns, Processes and Outcomes: Results from a Household Survey in Ponorogo, Indonesia". Working Paper No. 22 Falmer: University of Sussex. Yuda Prasetya dan Arif, Pujiyono. 2009. Analisis Produktivitas Industri Pengolahan di Jawa Tengah, di unduh dari eprints. undip.ac.iid. Jurnal TFP pada tanggal 28 Juli 2018. 